\title{
THE EFFECT OF NUTRITION AND EXERCISE
} EDUCATION ON THE DEVELOPMENT OF ATTITUDE AND BELIEF OF UNIVERSITY STUDENTS TOWARDS OBESITY: CASE OF ELAZIĞ PROVINCE

\author{
Üniversite Öğrencilerinin Şişmanlığa Yönelik Tutum ve \\ Inançların Geliştirilmesinde Beslenme ve Egzersiz Eğitiminin Etkisi: \\ Elazığ İl Örneği
}

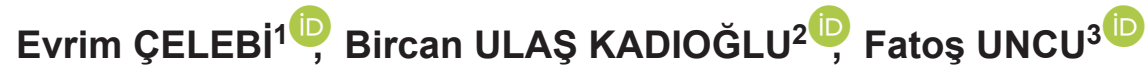

\begin{abstract}
In order to determine the effect of nutrition and exercise education on the development of students' attitudes and beliefs towards obesity, this study was conducted with a control group quasi-experimental pretest-posttest design. The research was conducted in the fall semester of the 2019-2020 academic year between October-November 2019. The study group consisted of 50 female students, 25 experimental (overweight or obese) and 25 control group (normal weight), studying at Fırat University Faculty of Health Sciences. In order to collect pretest data, a personal information form and Health Belief Model Scale in Obesity (HBMSO) were applied to the students in the experimental and control groups. Later, the students in the experimental group were taken to a 6 week program with 2 hours of healthy nutrition and exercise education per week. HBMSO, which was applied to the students in the experimental and control groups at the beginning of the study, was repeated at the end of the education, thus the posttest data were collected. When the before and after education HBMSO sub-dimension scores of the experimental and control groups were compared; The difference in the attitude to importance of health, perceived sensitivity, perceived severity, perceived usefulness and perceived disability dimensions in the experimental group was found to be significant $(p<0.001)$. HBMSO subscale scores of the control group did not show any difference $(p>0.05)$. As a result, after nutrition and exercise education given to obese students, a positive change was achieved in students' beliefs about obesity.

Keywords: Obesity, health belief model, university students.
\end{abstract}

Bu araştırma beslenme ve egzersiz eğitiminin öğrencilerin şişmanlığa yönelik tutum ve inançlarının geliştirilmesine olan etkisini belirlemek amacıyla, ön test-son test, kontrol gruplu ve yarı deneysel olarak yapılmıştır. Araştırma 2019-2020 eğitim öğretim dönemi güz yarıyılında Ekim-Kasım 2019 tarihleri arasında yapılmıştır. Çalışma grubunu Fırat Üniversitesi Sağlık Bilimleri Fakültesi'nde okuyan, 25 müdahale (kilolu veya şişman) ve 25 kontrol grubu (normal kilolu) olmak üzere toplam $50 \mathrm{kız}$ öğrenci oluşturmuştur. Ön-test verilerinin toplanmasında müdahale ve kontrol grubundaki öğrencilere kişisel bilgi formu ve Obesite Sağlık İnanç Modeli Ölçeği (OSíMÖ) uygulanmıştır. Daha sonra müdahale grubundaki öğrenciler 6 hafta süreli ve haftada 2 saatlik sağlıklı beslenme ve egzersiz eğitim programına alınmıştır. Müdahale ve kontrol grubundaki öğrencilere çalışmanın başlangıcında uygulanan OSiMÖ, eğitim sonunda tekrarlanarak son test verileri toplanmıştır. Müdahale ve kontrol gruplarının OSiMÖ alt boyut puanlarının eğitim öncesi ve eğitim sonrası karşılaştırılması yapıldığında; müdahale grubunun sağlığın önemi, algılanan duyarlılık, algılanan ciddiyet, algılanan yarar ve algılanan engel boyutlarında farkın anlamlı olduğu bulunmuştur $(p<0,001)$. Kontrol grubunun OSiMÖ alt boyut puanları farklıık göstermemiştir $(p>0,05)$. Sonuç olarak şişman öğrencilere verilen beslenme ve egzersiz eğitimi sonrasında öğrencilerin şişmanlığa yönelik inançlarında olumlu yönde değişim sağlanmıştır. Şişman ve şişmanlık riski bulunan kişilere sağlık inanç modeli temelli danışmanlık hizmetlerinin sunulması ve şişmanlığa yönelik tutum ve inançları değerlendiren başka çalışmaların yapılması önerilebilir.

Anahtar kelimeler: Şişmanlık, sağlık inanç modeli, üniversite öğrencileri.

1- Fırat University Faculty of Health Sciences, Midwifery Department, Elazığ, Turkey

2- Osmaniye Korkut Ata University, Faculty of Health Sciences, Nutrition and Dietetic Department,

Osmaniye, Turkey

3- Fırat University Faculty of Health Sciences, Nursing Department, Elazığ, Turkey

Sorumlu Yazar / Corresponding Author: Öğr. Üyesi Dr. Evrim ÇELEBI

e-posta / e-mail: ecelebi@firat.edu.tr

Geliş Tarihi / Received: 09.02.2021, Kabul Tarihi / Accepted: 05.05.2021

ORCID: Evrim ÇELEBI: 0000-0001-5641-5465

Bircan ULAŞ KADIOĞLU: 0000-0002-1150-8761

Fatoş UNCU: 0000-0001-8077-4652

Nasıl Atıf Yaparım / How to Cite: Çelebi E, Ulaş Kadıoğlu B, Uncu F. The effect of nutrition and exercise education on the development of attitude and belief of university students towards obesity: case of Elazig province. ESTUDAM Public Health Journal. 2021;6(2):138-47. 


\section{Introduction}

Overweight and obesity are defined as abnormal or excessive fat accumulation that may impair health (1). Obesity occurs when energy intake exceeds its output for an extended period of time. This imbalance is fueled by economic growth, industrialization, mechanized transport, urbanization and a nutritional transition to processed foods which have led to sedentary life style and unhealthy eating pattern (2). Obesity affects life quality and disability of people, therefore, it can have negative and indirect influences on society (3). Being overweight is a major risk factor for many chronic diseases such as cancer, diabetes and heart disease, and as such overweight and obesity should be viewed as global public health concerns (4). Increasing prevalence of obesity, seen both in the developed and developing countries, is primarily driven by imbalanced diets and sedentary lifestyles. Sedentary lifestyle that is characterized by physical inactivity has been associated with adiposity and increased weight gain (5).

In the last decades, obesity has become a pandemic health issue across developing and developed countries worldwide. In 2016, more than 1.9 billion adults, 18 years and older, were overweight. Of these over 650 million were obese. 39\% of adults aged 18 years and over were overweight in 2016 , and $13 \%$ were obese. Most of the world's population live in countries where overweight and obesity kills more people than underweight (1).

According to the Turkey Health Survey 2019 data, the percentage of obese individuals aged 15 and older was $19.6 \%$ in 2016 , increased to $21.1 \%$ in 2019 . In terms of gender, in 2019, $24.8 \%$ of women were obese and $30.4 \%$ were pre-obese, $17.3 \%$ of men were obese and $39.7 \%$ were pre-obese (6).

Since the early 1950s, the Health Belief Model (HBM) has been one of the most widely used conceptual frameworks in health behavior research, both to explain change and maintenance of health-related behaviors and as a guiding framework for health behavior interventions. Over the past two decades, the HBM has been expanded, compared to other frameworks, and used to support interventions to change health behavior (7). HBM aims to predict whether individuals choose to engage in a healthy action in order to reduce or prevent the chance of disease or premature death. The HBM addresses the effects of beliefs on health and the decision process in making behavioral changes (8).

The Health Belief Model argues that individuals' health behaviors will be affected by their beliefs, values and attitudes. If these beliefs and attitudes that are seen as problems are determined, the health education to be given or the treatment methods to be applied will be determined more suitable for that person. Identifying the perceptions underlying individuals' health-related attitudes and behaviors, and then correcting these identified wrong / missing aspects will put them into action. As a result, there will be more participation in early diagnosis and screening programs (9).

The transition from high school to college often results in drastic changes to environment and resources, and such changes likely impact health-related behaviors. Many studies have documented unhealthy behaviors among college students including decreased physical activity, increased rates of smoking and drinking, and decreased overall diet quality yet few studies have examined the change in behaviors that occur as students' transition from high-school to college (10). University students are quite vulnerable to obesity and overweight due to inadequate nutrition, and lifestyle, leading young people to conditions of potential cardiovascular risk (11).

In the prevention of obesity, it is necessary to increase the awareness of students about unbalanced nutrition and sedentary life issues, which are the leading changeable environmental risk factors. It would be beneficial to develop overweight and obese individuals' attitudes and beliefs about obesity and to support them with effective education. The main goal of this study is to determine the effect of nutrition and exercise education on the development of students' attitudes and beliefs towards obesity. 
This research had a control group quasi-experimental pretest-posttest design, and was conducted between OctoberNovember 2019 in the fall semester of the 2019-2020 academic year. The research was carried out with a total of 50 female students, 25 experimental (overweight or obese) and 25 control group (normal weight), studying at the departments of nursing, midwifery, nutrition and dietetics of Firat University Faculty of Health Sciences. Information about the research was given in the classes and the students who wanted to participate in the research were determined.

Body Mass Index (BMI) is widely used to determine obesity. BMI is obtained by dividing the individual's body weight $(\mathrm{kg})$ by the square of his/her height $(\mathrm{m})(\mathrm{BMI}=$ $\mathrm{kg} / \mathrm{m}^{2}$ ). Individuals were evaluated in two groups as overweight and obese, and normal according to their BMI values. $\geq 25$ of them were evaluated as overweight and obese and formed the experimental group, if $<25$, it was considered normal and formed the control group. The study included female students aged 18 years and over, who do not have any chronic diseases and volunteered to participate in the study.

The data were collected by the researchers using a questionnaire method. The questionnaire form consists of two parts. In the first part, there were personal information questions.

The questions were aimed at determining the general characteristics, eating and exercise habits of the individual.

In the second part, there was the Health Belief Model Scale in Obesity (HBMSO) consisting of 32 questions. The scale developed by Dedeli and Fadıloğlu consists of 32 items and is a measurement tool with high validity and reliability for our society (8). Obese individuals' attitudes and beliefs towards weight loss can be evaluated with the five dimensions of the Health Belief Model. These dimensions are; the importance of health, perceived susceptibility, perceived severity, perceived benefits, perceived barriers.

A personal information form and HBMSO were applied to the students in the experimental and control groups to collect the pretest data. After the pretest data were collected, the students in the experimental group were taken to a 6 -week program with 2 hours of healthy nutrition and exercise education per week. During this period, no education was given to the students in the control group. HBMSO, which was applied to the students in the experimental group at the beginning of the study, was repeated at the end of the education and post-test data were collected.

In the content of healthy nutrition education; The importance of nutrition, food-health relations, reducing the consumption of ready-to-eat (fast-food) food, consuming meals regularly and not skipping meals, reducing the consumption of foods with high sugar-fat content, avoiding one-way nutrition, balanced consumption of all kinds requirement were emphasized. In exercise education; the benefits of regular exercise to health and weight control were emphasized and a training booklet was distributed by explaining the types of exercise they can do.

Statistical analysis of the research data was made with the SPSS v21.0 data analysis program, and the data were expressed as number, percentage and mean. Chi-square test was used to compare the general characteristics, diet and exercise status of the students in the experimental and control groups. The Mann-Whitney $U$ test and the Wilcoxon Signed Ranks Test were used in the comparison of HBMSO sub-dimension scores of the students in the experimental and control groups within and between groups. In statistical analysis, the significance level was accepted as $p<0.05$ at 95\% confidence interval.

Approval was obtained from Firat University Non-Invasive Research Ethics Committee in order to conduct the research (11.07.2019/30/4). The aim and method of the research were explained to the students who constituted the research group, the voluntary consent form was read and their signatures were taken. It was stated that the identity of the participant and the information obtained during the research will be kept confidential.

After the education given to the students in the experimental group, a conference on nutrition and exercise was given to the students in the control group in line with the principle of equality. 


\section{Results}

In this section, findings obtained from research data are presented. The distribution of the socio-demographic characteristics of the students in the experimental and control groups is given in Table 1. The mean age of the students in the experimental group was $23.56 \pm 1.95$. $76.0 \%$ of the students in the experimental group stated that their family income was equal to expenses, mothers of $60.8 \%$ had an education level as literate and primary school graduate, fathers of $40.0 \%$ were a high school graduate, mothers of $80.0 \%$ were not working in any job, fathers of $68.0 \%$ had a job, $80 \%$ were living in nuclear families and $40.0 \%$ stated that the number of children in the family was between 3 and 4 . The mean age of the students in the control group was $23.76 \pm 0.72$. $64.0 \%$ of the students in the control group stated that their family income was equal to expenses, mothers of $76.0 \%$ had an education level as literate and primary school graduate, fathers of $36.0 \%$ were a high school graduate, mothers of $96.0 \%$ were not working in any job, fathers of $48.0 \%$ had a job, $84.0 \%$ were living in nuclear families and $44.0 \%$ stated that the number of children in the family was between 3 and 4 . It was determined that the students in the experimental and control groups showed similar distribution in terms of demographic characteristics and there was no statistically significant difference between the groups $(p>0.05)$.

Table 1: Distribution of the socio-demographic characteristics of the students in the experimental and control groups.

\begin{tabular}{|c|c|c|c|c|c|}
\hline \multirow{2}{*}{$\begin{array}{l}\text { Socio-demographic } \\
\text { characteristics }\end{array}$} & \multicolumn{2}{|c|}{$\begin{array}{l}\text { Experimental group } \\
\qquad(n=25)\end{array}$} & \multicolumn{2}{|c|}{$\begin{array}{l}\text { Control group } \\
(n=25)\end{array}$} & \multirow{3}{*}{ Test $^{* *}$} \\
\hline & & $\%$ & $\mathbf{n}$ & $\%$ & \\
\hline Age $\left(\bar{X} \pm S D^{*}\right.$, years $)$ & \multicolumn{2}{|c|}{$23.56 \pm 1.95$} & \multicolumn{2}{|c|}{$23.76 \pm 0.72$} & \\
\hline \multicolumn{6}{|l|}{ Family monthly income } \\
\hline Income > expense & 2 & 8.0 & 4 & 16.0 & \multirow{3}{*}{$\begin{array}{c}X^{2}=1.035 \\
p=0.596\end{array}$} \\
\hline Income $=$ expense & 19 & 76.0 & 16 & 64.0 & \\
\hline Income $<$ expense & 4 & 16.0 & 5 & 20.0 & \\
\hline \multicolumn{6}{|l|}{ Mother education level } \\
\hline Literate-elementary & 15 & 60.0 & 19 & 76.0 & \multirow{4}{*}{$\begin{array}{l}X^{2}=8.433 \\
p=0.077\end{array}$} \\
\hline Secondary school & 2 & 8.0 & 4 & 16.0 & \\
\hline High school & 6 & 24.0 & 2 & 8.0 & \\
\hline University & 2 & 8.0 & 0 & 0.0 & \\
\hline \multicolumn{6}{|l|}{ Father education level } \\
\hline Literate-elementary & 3 & 12.0 & 9 & 36.0 & \multirow{4}{*}{$\begin{array}{l}X^{2}=6.022 \\
P=0.198\end{array}$} \\
\hline Secondary school & 7 & 28.0 & 8 & 32.0 & \\
\hline High school & 10 & 40.0 & 4 & 16.0 & \\
\hline University & 5 & 20.0 & 4 & 16.0 & \\
\hline \multicolumn{6}{|l|}{ Mother's work status } \\
\hline Employed & 3 & 12.0 & 0 & 0.0 & \multirow{3}{*}{$\begin{array}{c}X^{2}=3.697 \\
p=0.157\end{array}$} \\
\hline Unemployed & 20 & 80.0 & 24 & 96.0 & \\
\hline Retired & 2 & 8.0 & 1 & 4.0 & \\
\hline \multicolumn{6}{|l|}{ Father's work status } \\
\hline Employed & 17 & 68.0 & 12 & 48.0 & \multirow{3}{*}{$\begin{array}{c}X^{2}=2.785 \\
p=0.248\end{array}$} \\
\hline Unemployed & 4 & 16.0 & 4 & 16.0 & \\
\hline Retired & 4 & 16.0 & 9 & 36.0 & \\
\hline \multicolumn{6}{|l|}{ Family type } \\
\hline Nuclear family & 20 & 80.0 & 21 & 84.0 & \multirow{3}{*}{$\begin{array}{l}X^{2}=1.024 \\
p=0.599\end{array}$} \\
\hline Extended family & 4 & 16.0 & 2 & 8.0 & \\
\hline Broken family & 1 & 4.0 & 2 & 8.0 & \\
\hline \multicolumn{6}{|c|}{$\begin{array}{l}\text { Number of children in the } \\
\text { family }\end{array}$} \\
\hline$\leq 2$ children & 7 & 28.0 & 4 & 16.0 & \multirow{3}{*}{$\begin{array}{l}X^{2}=1.088 \\
p=0.580\end{array}$} \\
\hline 3-4 children & 10 & 40.0 & 11 & 44.0 & \\
\hline 5 and over & 8 & 32.0 & 10 & 40.0 & \\
\hline
\end{tabular}

${ }^{*} S D$ : Standard deviation, ${ }^{* *}$ Chi-square test was applied. 
Table 2 shows the distribution of the nutrition and exercise habits of the students in the experimental and control groups. $52.0 \%$ of the students in the experimental group stated that they ate three main meals daily, $44.0 \%$ ate two snacks daily, $60.0 \%$ skipped some meals, $44.0 \%$ ate at normal pace, $60.0 \%$ indicated the amount of food they ate changed according to the psychological state and ate more, $76.0 \%$ did exercise to lose weight and $56.0 \%$ of them never did exercise. $56.0 \%$ of the students in the control group stated that they ate three main meals daily, $40.0 \%$ ate one snack daily,
$44.0 \%$ skipped some meals, $56.0 \%$ ate at normal pace, $48.0 \%$ indicated the amount of food they ate changed according to the psychological state and ate less, $76.0 \%$ did not exercise to lose weight and $68.0 \%$ of them never did exercise. When the nutrition and exercise habits of the students in the experimental and control groups were compared, it was seen that the answer given to the question, do you exercise to lose weight, differed significantly according to the groups $(p<0.001)$, and the groups were homogeneous in terms of other characteristics $(p>0.05)$.

Table 2: Distribution of the socio-demographic characteristics of the students in the experimental and control groups.

\begin{tabular}{|c|c|c|c|c|c|}
\hline \multirow[t]{2}{*}{$\begin{array}{l}\text { Nutrition and exercise habits of } \\
\text { the students }\end{array}$} & \multicolumn{2}{|c|}{$\begin{array}{l}\text { Experimental } \\
\text { group } \\
(n=25)\end{array}$} & \multicolumn{2}{|c|}{$\begin{array}{l}\text { Control group } \\
(n=25)\end{array}$} & \multirow[t]{2}{*}{ Test $^{*}$} \\
\hline & $\mathbf{n}$ & $\%$ & $\mathbf{n}$ & $\%$ & \\
\hline \multicolumn{6}{|l|}{$\begin{array}{l}\text { How many main meals do you } \\
\text { have a day? }\end{array}$} \\
\hline 1 main meal & 0 & 0.0 & 2 & 8.0 & $X^{2}=2.466$ \\
\hline 2 main meals & 12 & 48.0 & 9 & 36.0 & $p=0.291$ \\
\hline 3 main meals & 13 & 52.0 & 14 & 56.0 & \\
\hline \multicolumn{6}{|l|}{$\begin{array}{l}\text { How many snacks do you have a } \\
\text { day? }\end{array}$} \\
\hline No snacks & 4 & 16.0 & 6 & 24.0 & \\
\hline 1 snack & 8 & 32.0 & 10 & 40.0 & $x^{2}=1.511$ \\
\hline 2 snacks & 11 & 44.0 & 7 & 28.0 & $p=0.680$ \\
\hline 3 snacks & 2 & 8.0 & 2 & 8.0 & \\
\hline \multicolumn{6}{|l|}{ Do you skip meals? } \\
\hline Yes & 15 & 60.0 & 4 & 16.0 & \\
\hline No & 1 & 4.0 & 10 & 40.0 & $\begin{array}{l}x^{2}=3.000 \\
n=0223\end{array}$ \\
\hline Sometimes & 9 & 36.0 & 11 & 44.0 & $p=0.223$ \\
\hline \multicolumn{6}{|l|}{$\begin{array}{l}\text { How would you rate the way you } \\
\text { eat? }\end{array}$} \\
\hline Fast & 10 & 40.0 & 7 & 28.0 & \\
\hline Slow & 4 & 16.0 & 4 & 16.0 & $X^{2}=0.889$ \\
\hline Normal & 11 & 44.0 & 14 & 56.0 & $p=0.641$ \\
\hline \multicolumn{6}{|l|}{$\begin{array}{l}\text { Does the amount of food you eat } \\
\text { change depending on your } \\
\text { psychological state? }\end{array}$} \\
\hline No & 5 & 20.0 & 2 & 8.0 & $x^{2}=4783$ \\
\hline I eat less & 5 & 20.0 & 12 & 48.0 & $x=4.183$ \\
\hline l eat more & 15 & 60.0 & 11 & 44.0 & $p=0.091$ \\
\hline \multicolumn{6}{|l|}{ Do you exercise to lose weight? } \\
\hline Yes & 19 & 76.0 & 6 & 24.0 & $X^{2}=13.520$ \\
\hline No & 6 & 24.0 & 19 & 76.0 & $p<0.001$ \\
\hline \multicolumn{6}{|l|}{ How often do you exercise? } \\
\hline Never & 14 & 56.0 & 17 & 68.0 & $X^{2}=0.890$ \\
\hline 1-2 times a week & 9 & 36.0 & 6 & 24.0 & $p=0.641$ \\
\hline 3 times a week and more & 2 & 8.0 & 2 & 8.0 & \\
\hline
\end{tabular}

*SD: Standard deviation, ** Chi-square test was applied. 
Table 3 shows the comparison of the pretest and posttest HBMSO sub-dimension scores of the students in the experimental and control groups within and between the groups. While the scores of the experimental and control groups showed similar distribution in the sub-dimensions of health importance, perceived susceptibility, perceived severity and perceived barriers $(p>0.05)$, the difference between the experimental and control groups in the perceived benefits dimension was statistically significant $(p<0.001)$. When the before and after education HBMSO sub-dimension scores of the experimental and control groups were compared, it was found that the difference in the importance of health, perceived susceptibility, perceived severity, perceived benefits, and perceived barriers dimensions of the experimental group was significant $(p<0.001)$. HBMSO sub-dimension scores of the control group did not differ $(p>0.05)$.

Table 3: Comparison of pretest and posttest HBMSO sub-dimension scores of students in the experimental and control groups within and between groups.

\begin{tabular}{|c|c|c|c|}
\hline \multirow{2}{*}{$\begin{array}{l}\text { HBMSO } \\
\text { Sub-dimensions }\end{array}$} & Experimental group & $\begin{array}{l}\text { Control group } \\
(n=25)\end{array}$ & \multirow[t]{2}{*}{ Test $^{* *}$} \\
\hline & $\mathrm{X} \pm \mathrm{SD}^{*}$ & $\mathbf{X} \pm \mathrm{SD}^{*}$ & \\
\hline \multicolumn{4}{|c|}{ Importance of health } \\
\hline Pretest & $2.50 \pm 0.42$ & $2.67 \pm 0.54$ & $U=259.000 \quad P=0.297$ \\
\hline Posttest & $3.87 \pm 0.40$ & $2.47 \pm 0.63$ & $U=25.500 \quad p<0.001$ \\
\hline Test $^{* * *}$ & $Z=-4.323 p<0.001$ & $Z=-0.716 p=0.477$ & \\
\hline \multicolumn{4}{|l|}{$\begin{array}{l}\text { Perceived } \\
\text { susceptibility }\end{array}$} \\
\hline Pretest & $1.86 \pm 0.57$ & $2.33 \pm 0.73$ & $U=211.000 p=0.057$ \\
\hline Posttest & $4.09 \pm 0.72$ & $2.23 \pm 0.81$ & $U=36.500 p<0.001$ \\
\hline Test $^{\star \star *}$ & $Z=-4.350 p<0.001$ & $Z=-0.684 p=0.494$ & \\
\hline \multicolumn{4}{|l|}{ Perceived severity } \\
\hline Pretest & $1.23 \pm 0.43$ & $1.51 \pm 0.77$ & $U=216.500 p=0.055$ \\
\hline Posttest & $4.64 \pm 0.81$ & $1.74 \pm 0.96$ & $U=34.500 p<0.001$ \\
\hline Test $^{\star * *}$ & $Z=-4.422 \quad p<0.001$ & $Z=-0.991 \quad p=0.322$ & \\
\hline \multicolumn{4}{|l|}{ Perceived benefits } \\
\hline Pretest & $1.52 \pm 0.42$ & $2.71 \pm 0.92$ & $U=81.500 p<0.001$ \\
\hline Posttest & $4.34 \pm 0.65$ & $2.50 \pm 1.15$ & $U=74.500 p<0.001$ \\
\hline Test $^{\star \star \star}$ & $Z=-4.375 p<0.001$ & $Z=-0.729 p=0.466$ & \\
\hline \multicolumn{4}{|l|}{ Perceived barriers } \\
\hline Pretest & $3.93 \pm 0.41$ & $3.87 \pm 0.62$ & $U=243.500 p=0.179$ \\
\hline Posttest & $4.20 \pm 0.35$ & $3.62 \pm 0.62$ & $U=120.500 p<0.001$ \\
\hline Test $^{\star * *}$ & $Z=-3.873 p<0.001$ & $Z=-1.804 p=0.071$ & \\
\hline
\end{tabular}

*SD: Standard deviation, ** Mann Whitney U Test was applied, *** Wilcoxon Signed Ranks Test was applied

\section{Discussion}

In this section, the findings obtained from the research conducted to determine the effect of education given to university students on women's beliefs about obesity were discussed with the literature and similar research results.

There was no significant difference between the students in the experimental and control groups in terms of age, monthly income of the family, education status of mother and father, working status of the mother and father, family type and the number of children in the family. When the nutrition and exercise habits of the students in the experimental and control groups were examined, it was determined that they were similar in all variables except the habit of exercising to lose weight.

Education given to obese individuals according to the health belief model is an 
effective model to positively change individuals' beliefs about obesity and provide obesity management (12). When the before and after education HBMSO sub-dimension scores of the experimental and control groups were compared, it was found that the difference in the importance of health, perceived susceptibility, perceived severity, perceived benefits and perceived barriers dimensions of the experimental group was significant. The results of this study reveal the effectiveness of six-week nutrition and exercise education and show that education can significantly improve health belief model parameters. Similarly, in previous studies conducted with different populations, knowledge scores in the intervention group increased compared to the control group (13-22).

Health Belief Model is one of the intrapersonal health education models (derived from behavior science theory) which are administered for nutrition education in various subjects (22). The Health Belief Model argues that individuals' health behaviors will be affected by their beliefs, values and attitudes. If these beliefs and attitudes that are regarded as problems are determined, the health education to be given or the treatment methods to be applied will be determined more suitable for that person (23). Importance of health from HBMSO sub-dimensions; it expresses the importance of health according to the individual and the individual's attitudes and beliefs required to be healthy and remain healthy in general. In our study, although the pretest scores of the experimental and control groups were at a medium level, there was a significant increase in the scores of the students in the experimental group after the education and the difference was significant. This result shows that the education given positively affects the students' attitudes and beliefs necessary for being healthy. There was no change in the scores of the control group. Similar results were obtained in the studies conducted and it was found that education has a positive effect on nutritional behavior $(24,25)$.

The Health Belief Model (HBM) is one of the most widely-used frameworks developed to understand health behaviour. The HBM is recommended for nutrition education to increase the impact of educational programmes (26). The perceived sensitivity sub-dimension of HBMSO expresses a person's beliefs about the probability of contracting a disease or condition. The more a person feels at risk, the more he / she will reduce the risk-posing behavior $(7,9)$. It can be said that their perceived susceptibility towards obesity was low according to the pretest scores of the students in the experimental and control groups. After the education, the scores of the students in the experimental group increased significantly. In a study conducted in Iran, students' perceived susceptibility scores improved after nutrition education (26).

The perceived severity sub-dimension of HBMSO is how the severity or violence occurring in the individual is perceived against the consequences of the disease. This perception is particularly influenced by a person's health knowledge. If the person is informed about the general extent of the disease, his perception is affected accordingly (27). The pretest scores of the students in the experimental and control groups showed that their perceived severity towards obesity were low. However, after the education, the perceived severity of the experimental group were also positively affected and their scores increased. A study conducted in Southern Ethiopia supports our research finding and emphasized that the perceived severity has an important effect on improving nutritional knowledge (28).

The perceived benefits sub-dimension of HBMSO is the individual believing in the self-benefit of protective behavior suggested to protect from the disease or to reduce the severity of the disease (27). If the individual takes action on the issues he / she is sensitive to, he / she perceives the positive results as benefits (7). In our study, the perceived benefit pretest scores of the experimental and control groups differed significantly. Accordingly, the pretest scores of the experimental group before the education were low, while the scores of the control group were medium. 
However, the perceived benefits of the experimental group was positively affected after the education and their scores increased significantly. In a study conducted with medical students, the benefit perception scores of the students increased significantly after the nutrition education given based on HBM (29).

Perceived barriers, which is the last dimension of HBMSO, is individually perceived barriers in exhibiting new behavior and adapting to this situation (27). The potential negative aspects of a particular health action perceived may act as impediments to undertaking recommended behaviors. A kind of nonconscious, cost-benefit analysis occurs wherein individuals weigh the action's expected benefits with perceived barriers "It could help me, but it may be expensive, have negative side effects, be unpleasant, inconvenient, or time consuming". Champion and Skinner reported that perceived barriers were determined to be the most important factor in

\section{Conclusions}

In conclusion, following the nutrition and exercise education given to obese students in this study, a positive change was achieved in the beliefs of students about obesity, and there was a significant improvement in the importance of health, perceived susceptibility, perceived severity, perceived benefits and perceived barriers scores. Studies on this subject in Turkey is quite limited. For this reason, our study makes important contributions to the literature.

Other studies evaluating attitudes displaying behaviors as a result of many studies (7). It is seen that perceived barriers towards obesity were at a positive level according to the pretest scores of the students in the experimental and control groups. However, there was a significant increase in the scores of the experimental group after the education. There was no change in the scores of the control group. Our research finding is in line with previous research results $(26,29-31)$.

Like other studies, this study had some limitations. First, the limitations of the sample-size and limiting the study population to female students of university should be considered. We suggest future surveys with larger sample-sizes, diverse participants, and longer intervention periods to allow the results to be extrapolated to a larger population. Secondly, impact of the nutrition an exercises education was evaluated in a short period after completion of intervention and maintenance of behavior change needs longer follow up. and beliefs towards obesity can be conducted to determine what obese individuals see as obstacles to themselves, what they see as benefits and what they think about obesity. In this way, more effective steps can be taken by creating realistic policies in the fight against obesity. In addition, it may be suggested to establish education programs for the prevention of obesity and health problems that may develop due to obesity, and to provide health belief model-based consultancy services to people who are obese and at risk of obesity. 


\section{$\underline{\text { References }}$}

1. World Health Organization. Obesity and overweight. [cited 2021 Jan 14] Available from: https://www.who.int/news-room/ fact-sheets/detail/obesity-and-overweight

2. Ayed HB, Yaich S, Hmida MB, Trigui M, Jemaa MB, Jedidi J. et al. Prevalence, determinants and outcomes of general and abdominal obesity in medical students. Obesity Medicine. 2019;13: 39-44.

3. Vafainajar A, Vahedian SM, Tehrani $H$, Dogonchi M, Lael ME. The effectiveness of physical activity training on depersonalization and lack of accomplishment of employees. Iranian Journal of Health Education and Health Promotion. 2015;3(2): 116-24.

4. Gormley N, Melby V. Nursing students' attitudes towards obese people, knowledge of obesity risk, and self-disclosure of own health behaviours: An exploratory survey. Nurse Education Today. 2020;84:104232.

5. Kayode OO, Alabi QK. Food consumption patterns, physical activity and overweight and obesity among undergraduates of a private university in Nigeria. Clinical Nutrition Experimental. 2020;31:28-34.

6. TÜIK 2019. Türkiye Sağlık Araştırması 2019. [cited 2021 Jan 14] Available from: https://data.tuik.gov.tr/Bulten/Index?p=T urkiye-Saglik-Arastirmasi-2019-33661

7. Champion VL, Skinner CS. The health belief model. Health behavior and health education: Theory, research, and practice. 4th edition, Published by Jossey-Bass. 2008:45-65.

8. Dedeli O, Fadıloglu C. Development and evaluation of the health belief model scale in obesity. TAF Prev Med Bull. 2011;10(5):533-42.

9. Gözüm S, Çapık C. Sağlık davranışlarının geliştirilmesinde bir rehber: sağlık inanç modeli. Dokuz Eylül Üniversitesi Hemşirelik Fakültesi Elektronik Dergisi. 2014;7(3):230-7.

10. Wengreen HJ, Moncur C. Change in diet, physical activity, and body weight among young- adults during the transition from high school to college. Nutr J. 2009;8:32.

11. Iparraguirre RMP, Porras MM, De La Cruz AH, Bonilla MLD. Prevalence of overweight and obesity in Young Peruvian students at National University of Center of Peru-Region Junin-Huancayo. Obesity Medicine. 2020;19:100242.

12. Yaralı S, Hacıalioğlu N. Obezite Yönetiminde Sağlık İnanç Modelini Kullanma ve Hemşirenin Rolü. Gümüşhane Üniversitesi Sağlık Bilimleri Dergisi. 2020; 9(4):407 -15.

13. Abood DA, Black DR, Feral D. Nutrition education worksite intervention for university staff: application of the health belief model. Journal of Nutrition Education and Behavior. 2003;35(5):260-7.

14. Bhurosy T, Jeewon R. Effectiveness of a theory-driven nutritional education program in improving calcium intake among older Mauritian adults. The Scientific World Journal. 2013:1-16.

15. Diddana TZ, Kelkay GN, Dola AN, Sadore AA. Effect of nutrition education based on health belief model on nutritional knowledge and dietary practice of pregnant women in Dessie Town, Northeast Ethiopia: A cluster randomized control trial. Journal of Nutrition and Metabolism. 2018:1-10.

16. Hamuleh MM, Vahed SA, Piri A. Effects of education based on health belief model on dietary adherence in diabetic patients. Journal of Diabetes and Metabolic Disorders. 2010;9:1-6.

17. Iranagh JA, Motalebi SA, Mohammadi F. A Theoretically based behavioral nutrition intervention for elderly women: a cluster randomized controlled trial. International Journal of Gerontology. 2018;12(2):127-32.

18. Katsagoni CN, Apostolou A, Georgoulis M, Psarra G, Bathrellou E, Filippou C. et al. School teachers' nutrition knowledge, beliefs, and attitudes before and after an e-learning program. Journal of Nutrition 
Education and Behavior. 2019; 51(9):1088-98.

19. McArthur LH, Riggs A, Uribe F, Spaulding TJ. Health belief model offers opportunities for designing weight management interventions for college students. Journal of Nutrition Education and Behavior. 2018;50(5):485-93.

20. Nourian M, Askari G, Golshiri $P$, Miraghajani M, Shokri S, Arab A. Effect of lifestyle modification education based on health belief model in overweight/obese patients with non-alcoholic fatty liver disease: A parallel randomized controlled clinical trial. Clinical Nutrition ESPEN. 2020;38:236-41.

21. Shahnazi $H$, Abdolalian N, Kazemi A, Hassanzadeh A. Designing an educational intervention to prevent excessive gestational weight gain: a protocol for a randomized controlled trial. Reproductive Health. 2019;16(1):1-5.

22. Sharifirad GR, Tol A, Mohebi S, Matlabi $M$, Shahnazi $H$, Shahsiah $M$. The effectiveness of nutrition education program based on health belief model compared with traditional training. Journal of Education and Health Promotion. 2013;2:15.

23. Öz F. Sağlık alanında temel kavramlar. Ankara, Imaj İ̧ ve Dış Tic. A.Ş. 2004.

24. Alizadeh Siuki H, Jadgal K, Shamaeian Razavi N, Zareban I, Heshmati H, Saghi $N$. Effects of health education based on health belief model on nutrition behaviors of primary school students in Torbat e Heydariyeh city in 2012. Journal of Health. 2015;5(4):289-99.

25. Yaralı S. Obez kadınlara sağlık inanç modeline göre verilen eğitimin kadınların obeziteye yönelik inançlarına ve obezite yönetimine etkisi. [Tez]. Atatürk Üniversitesi Sağlık Bilimleri Enstitüsü; 2018.
26. Naghashpour $M$, Shakerinejad $G$, Lourizadeh MR, Hajinajaf S, Jarvandi F. Nutrition education based on health belief model improves dietary calcium intake among female students of junior high schools. Journal of Health, Population, and Nutrition. 2014;32 (3):420.

27. Hayden J. Health belief model. Introduction to health behavior theory. Canada. Jones and Barlett Publishers. 2009.

28. Yetnayet M, Henry CJ, Berhanu G, Whiting SJ, Regassa N. Nutrition education promoted consumption of pulse based foods among rural women of reproductive age in Sidama Zone, Southern Ethiopia, African Journal of Food, Agriculture, Nutrition and Development. 2017;17(3):12377-95.

29. Tavakoli HR, Dini-Talatappeh $H$, Rahmati-Najarkolaei F, Fesharaki MG. Efficacy of HBM-based dietary education intervention on knowledge, attitude, and behavior in medical students. Iranian Red Crescent Medical Journal. 2016: 18(11):e23584.

30. Shahroodi M, Tehrani $H$, Robat-Sarpooshi $D$, GHolian-Aval $M$, Jafari A, Alizadeh-Siuki H. The impact of health education on nutritional behaviors in female students: An application of health belief model. International Journal of Health Promotion and Education. 2019:1-13.

31. Tavassoli E, Reisi $M$, Javadzade $H$, Mazaheri M, Ghasemi S, Shakoori S. The effect of the health belief model-based education and improvement of consumption of fruits and vegetables: An interventional study. Journal of Health in the Field. 2017;1(2):5-12. 